\title{
Ilan Stavans's Latino USA: A Cartoon History (of a Cosmopolitan Intellectual)
}

Paul Allatson, University of Technology, Sydney, 2005.

Launched with considerable media coverage in 2000, Ilan Stavans's Latino USA: A Cartoon History, with illustrations by comic-artist Lalo Alcaraz, aimed to render accessible the history of the U.S.A.'s heterogeneous Latino sectors. ${ }^{1}$ In the Foreword Stavans justifies the book's comic format by distancing it from Ariel Dorfman and Armand Mattelart's Para leer al Pato Donald, which in English translation became How to Read Donald Duck: Imperialist Ideology in the Disney Comic. ${ }^{2}$ That 1971 study targeted the Disney comic as paradigmatic of U.S. cultural imperialism, a mass-cultural form capable of corrupting Third World youth with nefarious "American" capitalist and bourgeois individualist values. Stavans dismisses this argument as simplistic, tired, and tied to a bygone era of left-right Latin American antagonisms. Rather, Stavans insists, the worldwide popularity of the comic medium confirms that "Our global culture is not about exclusion and isolation, but about cosmopolitanism, which, etymologically derives from the Greek terms cosmos and polis, a planetary city" (xi). This appeal to an all-inclusive cosmopolitanism underwrites Stavans's desire for his cartoon history "to represent Hispanic civilization as a fiesta of types, archetypes, and stereotypes," and thus to avoid "an official, impartial tone, embracing instead the rhythms of carnival" (xv).

Concomitant with Stavans's ambitions to generate a highly playful historical text, Latino USA is also committed to elucidating the author's own personal history. As Stavans puts it, "History, of course, is a kaleidoscope where nothing is absolute. The human past and present are far more malleable than the future. This, in short, is my own account, a pastiche of angles I have made my own" (xv). Indeed, Mexican-born and raised Stavans consistently 
describes the genesis and final form of Latino USA in autobiographical terms: "The opportunity had arrived to become, finally, a manufacturer of kitsch, while paying tribute to a core aspect of my upbringing that I had cast aside when I focused my professional career on the muses of literature and academia" (xiv). This mix of avowed professional academic status and nostalgically qualified autobiographical desire has a direct authorial effect on the narrative's capacity both as history and as a contribution to Latino Studies. Not only is Latino USA filled with references to and endorsements of Stavans's own publishing backlist in Latino literature and culture, but the self-avowed cosmopolitan Stavans himself appears in the text as its dominant icon, at once the governing narrator, a sideline commentator on the narrative, and an active participant in Latino history.

With its ambitions stated, and the author's centrality in the text established, Latino USA is emblematic of the process by which Stavans has positioned himself at the forefront of U.S. Latino Studies. This status is exemplified by Stavans's stewardship of the first course in Spanglish offered by a U.S. university, ${ }^{3}$ and by a prolific publishing record that has helped to establish Latino Studies in the academy, and to spread the word about the latinization of the U.S.A. outside that country's campuses. ${ }^{4}$ Accordingly my interest here lies in tracing the impact of Stavans's cosmopolitanist view of Latino history, and his self-conscious insertion of himself into that history, on both Latino USA itself and the wider terrains of Latino Studies. Despite its popular cultural comic form, Latino USA helps to disseminate what I regard as an exclusive conception of latinidad. The fluidity and accessibility of Stavans's choice of medium for Latino USA is intended to parallel the boundary-crossing ease that the book - and other works by Stavans - celebrates as the basis of a cosmopolitanist and intellectual-centered trans-American notion of latinidad. This exclusive intellectual modality informs one of the selling-point laudations on the book's back cover, from Richard Rodriguez: "Not since Octavio Paz has Mexico given us an intellectual so able to violate 
borders with learning and grace." Overlooked in this rhetorical violation of borders, of course, are those Latinos who lack the requisite credentials of transnational and transcultural mobility reified in Latino USA and other texts authored by Stavans. Related to the borderviolating credentials of its author, Latino USA contains a cluster of historiographical, taxonomic, geopolitical, and personal interests that also invite scrutiny. In focusing on these interests I have two concerns. First, to determine the extent to which Latino USA consolidates the figuration of Latino discourse as a "planetary" realm of and for one cosmopolitan subject. Second, to explore how Latino USA typifies Stavans's appropriation of Latino history and discourse so there can be no "Latino" without Stavans as and at its authorizing center.

My reading of Latino USA, then, emphasizes the impossibility of disentangling the text's author from its "author-function." This is the French philosopher's Michel Foucault's term for the author's appearance and function in discourse. For Foucault discourse refers to a body of related statements and utterances that combine to generate, normalize and institutionalize a narrative of reality and associated claims to truth and knowledge, and that to some degree detach texts from the real world subjects responsible for the writing. ${ }^{5}$ Four qualities characterize the author-function. It is inseparable from the discursive productions of various (state) apparatuses (legal, educational, publishing, and so on). It is mutable and multifaceted, as befits its appearances in a range of intersecting historical and sociocultural contexts. The author-function is dependent on the processes by which a writing subject is discursively framed and produced as an "author." In turn, this framing may produce an author with "a variety of egos" and "subjective positions," irrespective of the writing subject's class origins (130-31). Foucault, moreover, also identifies authors who occupy a "'transdiscursive' position" (131). Such authors-Marx and Freud are his examples_-are "initiators of discursive practices" in that their texts became the basis of theories, traditions and disciplines, or bodies of knowledge (131). Foucault nonetheless cautions that the change of emphasis 
from author to author-function does not quite entail the death, absence or irrelevance of a living-breathing author or a writing subject. As he says, "it would be false to consider the function of the author as a pure and simple reconstruction after the fact of a text given as passive material, since a text always bears a number of signs that refer to the author."

Accepting that the real-world author shadows the author-function, my contention with regard to Latino USA: A Cartoon History is that it does matter "who's speaking," to cite Foucault. ${ }^{7}$ There is a tension inherent to this text between the discursive author-function and what the Palestinian-born critic Edward Said would call the text's discursive situation or worldliness, the web of "historical, ideological, and formal circumstances" in which a text enters the world as a product and symptom of power contests. ${ }^{8}$ Certain discursive and material power struggles are occluded by Stavans's investment in presenting Latino history in a comic format, one that he insists attends to historical contradictions while promoting discursive innocence and eschewing "high" for "low" cultural (comic-kitsch-fiesta-carnival) qualities. The viability of Latino USA as history pivots on two related dynamics: first, the discursive role played by the author-function in the text; and second, the impact of the writing-subject Stavans himself on the comic's specific take on Latino history. As a consequence of these dynamics, the comic's playful coordinates and its foregrounding of historical contradictions paradoxically permit Stavans, the writing subject, to overdetermine and distort the history and civil rights struggles that are his ostensible topic.

The approach outlined here suggests the need for a clarifying statement on terminology. Although Stavans calls his narrative a "Cartoon History," I regard it as a comic that falls into the genre of history. I borrow this approach from Scott McCloud's Understanding Comics, a didactic comic about the comic medium, in which he distinguishes between a cartoon (a single panel) and a comic (“juxtaposed pictorial and other images in deliberate sequence," presented on the page in panels). ${ }^{9}$ I also follow his lead in separating pictorial from written 
text or script. In my reading, nonetheless, I leave uninterrogated the issue of the cartoonist Lalo Alcaraz's possible inputs to the narrative's governing protocols. ${ }^{10}$ The Foreword leaves little doubt that narratorial responsibility is claimed by Stavans alone; accordingly I cannot speculate on Alcaraz's role in Latino USA beyond the level of his aesthetic and visual contribution, and his panel appearances as a character. This proviso accords with Martin Barker's argument that the comic's "meaning" is not determined by its formal qualities alone, but also by "the kind of relationship into which the reader is invited." "My analysis, then, is concerned with the impact of Stavans, as biological subject and author-function, on the ways by which Latino USA invites interpretation as a comic-framed historical narrative within Latino discourse. $^{12}$

\section{The logics of historical integrity}

Since the late 1970 s the notion that the U.S.A. is undergoing an inexorable process of latinization has gained wide currency. But rather than simply chronicle this process, many Latino cultural producers and critics have been concerned to debate how, if at all, the process is enabling a broad identification or affiliation, latinidad, under which people from diverse sectors may assert, and insert, their aspirations in U.S. political structures and modes of representation, as well as in transnational and continental imaginaries. As Chon Noriega describes it, the strategic use of Latino arose "because - in the popular imagination, governmental classification, and mass media distribution — specific Latino groups are not understood in national terms." ${ }^{, 13}$ For Noriega, Latino does not signify an ethnic identity that overrides specific national or minority identities - Chicano, Mexican, Puerto Rican, Cuban, and so on-in the U.S. context. Rather, Latino connotes "the hilo/thread for a social movement to remap 'America,' and — in a more immediate sense - for negotiating the representation of specific histories/identities as part of the national culture" (46). To some 
extent, these prospects and ambitions remain undefined, for as Frances Aparicio argues, the movement's critical practitioners operate within an "academic imaginary." That is, Latino Studies is "a potential rather than fact, a field very much in its initial makings despite the three decades of scholarly production in Chicano Studies, Puerto Rican Studies, and the emerging Cuban-American, Central American and Dominican scholarship.",14

Given that the debates around latinidad emanate from a dynamic field-in-the-making based on diverse bodies of sophisticated scholarship, and characterized by institutional heterogeneity and multi-disciplinarity, the role of a text such as Latino USA is particularly timely. Not simply a popularizing and accessible account, Latino USA's significance would thus seem to rest or fall on its ability to synthesize previous criticism, and to connect the historical experiences of the U.S.A.'s Latino sectors to broader historical currents in the Americas. As a historical narrative emerging from and circulating within Latino discourse, Latino USA takes a playful approach to its governing brief, one that nonetheless impels its author to take certain ideological and aesthetic stands on the problem of how to manage the task of historical construction. "Nonsense," says Stavans in the book's Foreword, in reaction to the line taken by Dorfman and Mattelart that "Walt Disney's characters, so the litany goes, are hardly about innocence" (xi). This reaction does not simply confirm Stavans's opposition to certain strands of 1960s and 1970s Latin American Marxism. It also places him at loggerheads with Foucault and Said, both of whom strenuously discredit the alibi of textuality's discursive innocence. To complicate matters, Stavans regards the comic medium as somehow immune to discourse, and thus able to control it, even to the point of disarming its disciplinarian potential. The comic's formal "unofficialness," he says, provides Latino USA with "a less Europeanized, more democratic viewpoint" (xv). Moreover, Stavans also sees in the comic format a manifestation of the carnival and its purportedly subversive qualities. While the Russian theorist Mikhail Bakhtin regarded the carnival as a social venue 
in which "low" democratic impulses could and did irrupt into social prominence, he also saw in it an ambivalent because short-lived and ultimately unthreatening response to prevailing political agents and institutions. ${ }^{15}$ Stavans, on the other hand, asserts that his carnivalesque approach confirms the "historical integrity" and democratic credentials of his text. His democratic reading of Latino history, he claims, thus derives from and survives intact the cartoon's "mischief and caprice," its "purposeful imitation" and anarchy, its "inherently theatrical and humorous nature," and its "freshness, imagination, caricatures, and fantastical and delightfully irreverent overtones" (xiv-xv).

This commitment to "historical integrity" is tempered further by other factors, including Stavans's own biography and textual appearances, which challenge faith in the discourse of historical transparency that purportedly moderates Latino USA. According to its table of contents, Latino USA is divided into the already noted Foreword (the only part of the book not in comic form), an introduction, four main historical parts, a bipartite Epilogue"Meet the Author, Then Run!," and "Welcome to the Future, Señor!"-an acknowledgements section, and an index. As the Epilogue's titles reveal, an icon of the Author figures prominently in his comic history. Readers encounter this Author throughout the narrative that follows and he is introduced, along with a "festive" cast of players, on the page facing the Introduction. Easily recognizable with his trademark spectacles and foppish, left-parted fringe, the Author provides commentary on the historical narrative and features in many panels as an active historical agent. He is joined and supported in this interventionist endeavor by a Toucan, included as the book's magical realist signifier, a female school teacher (la Maestra) whose presence confirms the comic's didactic ambitions, and a Calavera, a skeleton based on the engravings by the Mexican artist José Guadalupe Posada. Lesser cast players are also introduced: the Mexican film star Cantinflas; the Mexican wrestler-cumsocial-activist El Santo; the latter's Anglo "nemesis," Captain America; the Chicano 
Cartoonist Lalo Alcaraz ("Este vato loco") responsible for the comic's black and white images; and finally, The Publisher, "the guy who counts the pennies," represented a la George Grosz from the shoulders up as a solid block of blackness with hat and smoking cigar. These are not the only regular actors. Other Latin American figures, including Che Guevara and Frida Kahlo, make repeat appearances in Latino USA, but unlike the four main players, they (and the lesser cast players, bar the Cartoonist) are not permitted to clarify, comment on, or dispute the historical narrative containing them.

The theatrical allusions by which these characters are introduced to the sequential format of the comic support Stavans's plan for Latino USA to present an irreverent historical entertainment; it is to be enjoyed, not deeply assessed, by its readers. As the comic's recurrent icons, the regular players also facilitate the transitions from panel to panel, and contribute to a sense of continuity as the diegesis, or the comic's in-built commentary on its own historical narrative, sweeps over, and shifts between, distinct historical eras and geopolities. Yet these "naturally thespian" players (xiv) are also the main devices by which the comic diegesis purports to present and yet to toy with narrative cohesion, to transmit complicating nuances, and to generate (panel by panel, and within each panel) argument and differences in position. The approach recalls the Brechtian strategy of estranging audience expectations of witnessing the represented "real," and of recognizing themselves in that representation, through a rigorous unsettling of the (dramatic) work of art's formal conventions, a laying bare of its artifice and constructedness. Indeed, as if anticipating and abetting reader alienation from his rhetorical asides and running commentary, and the historical trajectory he directs, the Author is defined in self-deprecating terms: "Scientific name Deus obnoxious spanglishicus. Responsible for the following mess. Most of us here don't really like him" (xvi). As the sardonic putting under erasure of "don't" here suggests, the obnoxious Spanglish-speaking God-Author is shown reveling in his role as popularity 
contest contender, and yet making provision for popularity failure.

This deistic Author, of course, is not the same as the subject who goes by the name of Ilan Stavans. Rather, he is the narratorial presence that, according to Foucault, operates as a textual stand-in for the real-world writer, and thus "as a complex variable function of discourse. $" 16$ To Stavans, the supreme arbiter in Latino USA, are owed the titles of the four key sections, and the teleological logic they obey and convey: "Conquest and Exploration: 1492-1890"; "Into the Cauldron: 1891-1957”; "Upheaval: 1958-1977”; and, "In Search of a Mainstream: 1978-Mañana." Even before readers get to the first section, then, the comic's temporal organization pushes history in one discursively laden direction. Latino history, indeed American history in its broadest topographical sense, is inaugurated in 1492 with Columbus's first voyage. "He was the one," says la Maestra while pointing at a map of the Atlantic, "to unite the old and the new continents" (13). In the narrative that unfolds, this choice of historical origin effectively discounts all claims to modern-world status of indigenous Americans. The continent's Native peoples are swallowed up in the saga of European expansion and imperial success. They become the recipients of the Eurocentric viewpoint that the defeat and demise of Native peoples can be attributed to the inherent (socio-cultural, textual, technological, human) lacks of conquered indigenous peoples when compared to purportedly more "civilized" European cultures and peoples. ${ }^{17}$ Despite solid attentions to the fate of Meso-Americans after the Spanish conquest, the sidelining of preColumbian cultures goes unremarked, even when the Calavera asks pointed questions"Whose big idea is that?" (12)—about the decision to opt for the Columbian genesis: "Every history starts with this poor misunderstood Italian. Couldn't we begin elsewhere?" (13). Later, in a discussion of the Chicano Movimiento in the 1960s and 1970s, the inclusion of a 
statement from activist and journalist Rubén Salazar suggests that the comic history has not been swayed by Chicano critiques of the Columbian-genesis thesis: "He [a Chicano] resents being told Columbus 'discovered' America when the Chicano's ancestors, the Mayans and the Aztecs, founded highly sophisticated civilizations centuries before Spain financed the Italian explorer's trip to the 'New World"' (130).

Nonetheless, the historiographical problem of ascertaining a beginning and a viable structure for Latino USA does affect the Author, whose anxiety on this score is rendered as two drops of sweat flying from his forehead: "How would you divide history? By definition, history has neither beginning nor end, but it is a neverending flux. It's the historians who are setting the limits" (12). Having set the beginning limits of Latino USA, the Author will later conclude "that history is a theater of possibilities" (166). In the intervening narrative, however, constraints on the theatrical possibilities celebrated at the comic's opening and close are evident. Responding to the Author's "what if?" scenarios about the Aztec colonization of Europe - a rhetorical inversion of the Euro-narrative of discovery, a favored trope of possibility in much Chicano cultural production ${ }^{18}$ - the Cartoonist asks, "The winner sets the rules, no?" (20). The drawing of attention to the proliferation of victors' narratives in the post-1492 epoch is alluded to later in a discussion of the Civil Rights era, and the Author's own question: "What is it that one win's in history?" (134). This, perhaps, is the central question posed by Latino USA; the comic's players constantly seek answers to it, including "better conditions, equal opportunities," and consciousness-raising "of the plight of MexicanAmericans and other Latinos," even if their overall assessment of such gains is pessimistic: "Not much has changed as a result" (134).

And yet this historiographical debate is not solely concerned with chronicling wins and 
losses. In a debate about historical exclusion and inclusion, ostensibly spinning off the importance to Latinos of 1848 (the end of the Mexican-American War) and 1898 (the Spanish-American War) as temporal "milestones," the Toucan, the Calavera and the Author argue over the role of Latino USA as history. The Toucan, worried about its place in the sequential narrative, and by the comic's originality, is reassured by the Calavera: "Well, originality is a tough term. See that library? How many books in it do you think are truly original? Besides, history has a set, predictable plot, but there's little room for creativity" (59) The Toucan, he adds, should be "thankful" that the Author "created us, we're figments of his imagination." Moreover, the Calavera posits that the Author-shown reading Don Quijote in a library whose shelves include Stavans's own The Hispanic Condition ${ }^{19}$ — has been an exemplary historian, not "miss[ing] any major event in history so far" (59). In this discussion, history is implied to be a dry catalogue of verifiable dates and facts. It is not deemed to share fiction's inventive imperatives, and its selective, exclusionary, and arbitrary ordering principles. However, the message to readers on this score is ambivalent, for the comic's function as historical record appears to collapse in the contradictory shifts between, on the one hand, self-conscious recognition of historical artifice, and on the other, anxious appeals to historical verisimilitude. Latino USA is arraigned against the fixed predictability or eventuality of history because of the Author's "unofficial" ambitions (xv), here codified in comic format. And yet the narrative's "unoriginality" and playfulness are also claimed by the Author to respect "major [historical] events." It is thus never clear whether Latino USA approaches history as a narrative construct open to myriad interpretations and manipulations, or as an empirically substantiated and finite list of occurrences.

It could be argued that this diegetic slipperiness does not matter within the governing 
"festive" logics of the narrative. History provides the Author with an appropriate generic vehicle for indulging his sense of play while claiming to respect historical truth. Nonetheless, it is also possible to recognize that this Author-directed play generates a see-sawing dynamic between opposed notions of history — rather than an acceptance that in historical discourse, truth (events) and fiction (historians' subjectivity; narrative construction) defy disentanglement - thereby marooning the players in a script of constant contradiction, equivocation, and generalization. Within the comic's overarching teleology, these effects are fixed by the four historical divisions, the first being "Conquest and Exploration: 1492-1890." The dating here suggests a neat continuum from Spanish imperial to later U.S. national expansions, although the section bypasses Spanish colonization in the Caribbean and covers only those territories now subsumed into Mexico and the U.S. southwest. From this initial stage the narrative moves to "Into the Cauldron: 1891-1957," presented as the era of hemispherical events responsible for the first significant mass migrations from Latin America to the U.S.A. This is followed by "Upheaval: 1958-1977," which describes the Cuban Revolution and the rise of various Latino protest movements, and finally, "In Search of a Mainstream: 1978-Mañana," whose title and content propose that Latinos, like Latino USA, are about to reach the desired teleological endpoint of social respectability and national significance, if not political power.

Stavans's speculative vision of Latino history as the movement of Latinos toward inevitable mainstream success and influence informs much of his writing. Similar speculations on Latino history, for example, are evident in his The Hispanic Condition: "Ours is Moctezuma's revenge. We shall infiltrate the enemy, we shall populate its urban centers, marry its daughters, and re-establish the kingdom of Aztlán. We are here to reclaim what we were deprived of, to take revenge. This isn't a political battle, a combat often stimulating to the liberal imagination, but a cosmic enterprise to set things right. ${ }^{, 20}$ Aside from the 
masculinist, heteronormative desire at work here-Stavans's "we" excludes women and queers - the rhetoric, like that in Latino USA, exemplifies what Chon Noriega has targeted as the "Sleeping Giant" allegory. This refers to the process by which "Latinos are imagined or represented as 'potential citizens' rather than as actual ones. The struggle over civil rights, political representation and cultural pluralism, then, becomes an agenda for some future date, with the onus placed upon a hypothetical image for the Latino community. And while the giant sleeps, it has no past and no present." ${ }^{21}$ Noriega is especially critical of Latino intellectuals who have popularized the Sleeping Giant thesis and "undertaken a leveraged buyout of Latinidad based on its future performance (in consumption, reproduction, electoral politics)" (47). This is precisely the message transmitted by the Author's concluding line in Latino USA that "history is a theater of possibilities" (166). Under the Stavans authorfunction, which is driven by the thesis that "The sleeping giant can (and will soon) awaken," Latino social struggles of past and future become play, the matter of allusion and illusion, not historical-material action and hard-fought achievement. ${ }^{22}$

These speculative concerns for the Latino future aside, the comic's linear approach to the Latino historical record is under internal pressure in other ways. Little assistance is given to readers to ascertain the precise reasoning behind the comic's arbitrary temporal divisions or their historical content, and at times, historical events are discussed in apparent disregard of the comic's temporal dynamic. For instance, to mention three oddly positioned examples, the "1891-1957" section includes the sixteenth-century discourse of the Black Legend (a demonization both of the Spanish character and the Spanish imperial project that arose among Spain's rivals in largely Protestant northern Europe), the "appearance" of la Virgen de Guadalupe to Juan Diego, and the emergence of Latin American states, Mexico excepted, since its national genesis is noted earlier. Another oddity occurs in the panel that details the coming to independence of Spain's Latin American colonies. Here, the Maestra recalls that 
Puerto Rico achieved its independence from Spain in 1897, a claim that would surprise residents of the island, then and now (49). ${ }^{23}$ The Author, however, has a comment on the narrative's "playful" approach to historical content that provides him with an explanation of sorts, an appeal to the systematic biases inherent to all historical endeavor: "History is nothing but the attempt to systematize human memory. And memory is so fragile, so subjective. Each historian ends up writing an account that is suitable, convenient to him [sic], that justifies the past in his [sic] eyes" (98). Disguised by this admission is the link between the Stavans author-function's ability to center a discourse in specific institutional contexts, and the process by which those discursive and institutional sites direct substantial benefits to Stavans, the writer subject.

\section{Discursive innocence or interest?}

As the Author admits, it is impossible to avoid constructing his, indeed any, historical narrative without recourse to such criteria as suitability, convenience, and self-justification. Yet this explanation also implies that the scripted approach to the complex processes of U.S. latinization adopted in Latino USA cannot be anything but discursively weighted, despite the Author's claims about the comic's ideological innocence. Symptomatic of this discursive weight are the many appeals to lowest-common denominator ethnic clichés, as exemplified by the Author's intervention, delivered from the panel sidelines, that "Pan y circo, tacos and soccer, is what Latino culture is all about" (9). Indeed, when the Toucan says that "Latino history is like a crowded fiesta: masks, music, and endless energy!," the Author's response"What a cliché!" (11)—confirms his functional inconsistency, since throughout Latino USA he is often the device responsible for similar typecasting. Even in moments when the stereotyping urge is parodied, it is clear that the Author's rhetorical flourishes amount to a relentless tropicalization of Latin(o) peoples and cultures. According to Aparicio and 
Chávez-Silverman, tropicalization refers to a "system of ideological fictions [by] which the dominant (Anglo and European) cultures trope Latin American and U.S. Latino identities and cultures." 24 Two simultaneous trajectories are evident in this system. First, tropicalizations of Latinos - the production of tropes characterized by references, among others, to an eroticexotic, dark and sinuous "Latin" sensibility, to superstitious-cum-magical Catholicism, to heat, spice, emotionality, musicality, and barely repressed violence — are "distributed among official texts, history, literature, and the media" and disseminated throughout U.S. society (8). Second, and in dialectical tension with official tropicalizations, Latinos may attempt to appropriate such "ideological fictions" in their own cultural-political productions, the aim being to divest them of their negative connotations, to resemanticize and politicize them, and to recirculate them as Latino friendly images (12). That said, Aparicio and Chávez-Silverman warn, this counter-hegemonic struggle at the level of representation can and does not preclude Latinos from tropicalizing themselves. Latinos, too, may produce and distribute damaging tropes of latinidad in ways that replicate and mirror dominant-cultural protocols (11).

Latino USA is filled with examples of damaging tropes of latinidad as its ethnicized tropicalizations merge with gendered ones, thus undermining the Author's claim to construct what Barker calls "an authentic collective representation.",25 In one of the Author's what-if speculations, he asks, "What if our [an undefined possessive in the script] view of beauty had Indian women, bronze, svelte, stunning, as its ideal, and not its Iberian counterparts?” (20), thereby betraying his heteronormative eroticization of Native ethnicity, and reiterating the point he makes in the Foreword that a "beautiful señorita" (another recurring icon in Latino USA) encapsulates "the exuberant sexuality I grew up with" (xv). Later, when discussing the representation of Puerto Ricans in West Side Story, the Calavera mocks a prevailing cultural assumption that "all Latina girls [are] named María" (99). But the critique appears to be 
forgotten a few pages later when the setting shifts to Dade County, Florida, and a Spanishlanguage teacher and her student parrot the line, "Yo me llamo María" [My name is María] (106). These "Marías" may well be intentionally named. But they also support a more literal counter reading. Despite the Author's argument with "the recurrence of stereotypes," that critical stance is invariably followed, in the same or following panel, by enthusiastic endorsements of a Latin(o) "tropical spirit" (44-45).

Aside from establishing the tropicalizing contours of the Author's script, the Introduction also attempts to define "Latino" peoples and to explain why they are of narrative interest in the comic's four historical sections. The Introduction emphasizes the profound sociocultural and political changes brought about by the numerical increase in Latino populations in such areas as cuisine, language use, sport (the rise of soccer), electoral power ("We will be able to decide who the next President is" [9]), and racial/ethnic make-up. The entire narrative, in effect, works toward validating the Author's take on the historical inexorability of U.S. latinization. Confirming his reading of U.S.-Latin American relations as the temporal lead up to a preordained Latino order, the projected statistics on the demographic break-up of U.S. sectors in 2025 are rendered in an "enchilada"-another tropicalizing sign — superimposed on mainland U.S.A., with Latinos (23\%) shown to be more numerous than Blacks (17\%) and Asians (21\%), but not yet as numerous as Whites (29\%) (8). The U.S. future portrayed in Latino USA will soon be seamlessly Latino. But that speculative drive is nonetheless preordained by the comic's representation of the "American" past as U.S. "Latino" history. Anything and everything, it seems, can be appropriated into that history, from Spanish colonization and Catholic evangelization to the Monroe Doctrine, from Cabeza de Vaca's chronicle of shipwreck and survival and Stephen Crane's writings on Cuba to magical realism, from slavery and Latin American nation-building to West Side Story, from I Love Lucy and Cantinflas to the Mariel boatlift, from Pablo Neruda's poetry and 
Diego Rivera's murals to barrio graffiti, and, from Time cover images and U.S. space exploration to Stavans's own published backlist.

While the playful provisions of data and topics of coverage in Latino USA do convey some sense of the far-reaching demographic impact on U.S. society generated by U.S. expansion and hemispherical power, and of ongoing mass migration from Latin America, that playfulness also impacts on the way those populations are conceived and identified in the comic. The text foregrounds the term Latino, but grudgingly, as attested by the Author's description of it as an "in-vogue" term, and his prediction that by the time readers get to the text, another term will have replaced it (7). The Author, in fact, prefers the term's rival—- I like 'Hispanic' the best" (7) — thereby dispensing with the longstanding Latino critical debate over terminology, much of it generated in angry response to successive U.S. government usages of Hispanic, that has dominated Latino discourse since the late 1980s. The Author's preference for Hispanic is balanced, at least in the panel in which it appears, by the Cartoonist's reaction, "His Panic makes me panic!” (7), but the comic glosses over the political tensions alluded to in this contrast in opinion. In the enchilada-chart, moreover, "Latino" is conceived as a "minority group" of the same conceptual order as "white," "black" or "Asian," that is, a racialized category. "Spanish" is often used in the comic, although the script does not clarify if this designation refers to a national, linguistic or culturally determined collective: "In 1776, when the declaration of independence was announced there was no Spanish presence in the new United States of America. That wouldn't happen until the first Puerto Ricans and Cubans arrived in 1853" (25). ${ }^{26}$ The Author also expands Hispanic/Latino so that either term can encompass Spaniards; thus, Felipe Alfau becomes a "Latino" writer, not a Spanish-migrant writer (60). The inclusion of "Spain" under the Latino rubric also leads to identificatory anachronisms, exemplified by the panels in which the Calavera describes the Conquistador and writer, Cabeza de Vaca, as the "first Latino to be 
lost," an ironic reference to the many years spent by the shipwrecked Spaniard among Native Americans in what is now U.S. territory in the sixteenth century (16). Elsewhere, the Movimiento is referred to as a Latino phenomenon, rather than a Chicano civil rights enterprise (109).

At the very least, the many identificatory options on view in Latino USA reveal confusion over what and who precisely is being discussed. While this does perhaps reflect the innate instability and contestability of the identity terms themselves, the presentation of taxonomic uncertainty in the comic tends to flatten the demographic and aspirational complexities and conflicts (most obviously racial, but also class and gender/sexual) between and within what the text calls Latino "subgroups" (8), collectively the most racially mixed of U.S. populations. The proliferation of options thus echoes the homogenizing aims of the U.S. Census, which in 2000 provided three terms of purported equivalence-Spanish, Hispanic, Latino - by which respondents could self-identify. The Census Bureau's conflation of Latino, Hispanic and Spanish suggests that this particular U.S. state apparatus regards identifications based on linguistic (Spanish, Hispanic), national (Spanish), and ethno-cultural (Spanish, Hispanic, Latino) factors as synonymous. ${ }^{27}$ By also regarding the three terms as interchangeable, Latino USA perpetuates a similar logic.

These signifying moves link Latino USA to other texts in which the Stavans authorfunction is at work. In an interview posted in the Spanish e-journal Cuadernos Cervantes, Stavans rejects the term minority to designate U.S. Hispanics, and proposes that they comprise a set of national groups united by a common language and historical heritage. ${ }^{28}$ Hispanics as defined here must speak Spanish, thus disenfranchizing millions who speak English only. And by assuming that "historical heritage" is shared, and provides a coherent vector of communal identification, Stavans overrides the disparate and often conflict-ridden historical experiences of U.S. residency, and of Spanish colonialism, between and within 
Latino groups. The taxonomic conundrum continues in one of Stavans's more detailed comments on the Hispanic versus Latino debate:

Hispanic, generally preferred by conservatives, is commonly used when discussing demographics, education, urban development, or health policy. Latino is generally preferred by liberals and is more often than not applied to artists, musicians, and movie stars. The government uses Hispanic to describe the heterogeneous ethnic and cultural minority with ancestors across the Rio Grande and in the Caribbean archipelago. But the majority of citizens of that region acknowledge Latin America as the correct English designation. ${ }^{29}$

But later in the same article he opts for Hispanic - "a more accurate and convincing term and thus I'll stick with it" (3) — unabashed by the fact that this choice allows him to be identified, according to his own wording, as a conservative. As with Latino USA, however, the Stavans author-function also at times uses Hispanic as a linguistic signifier only, "because language is the main factor here, a vehicle of one's thoughts. ${ }^{, 30}$ Finally, yet another take on terminology is proposed in The Hispanic Condition. Faced by the rise of Latino, a term he has always distrusted, Stavans feels authorized to pronounce: "I herewith suggest using Latinos to refer to those citizens from the Spanish-speaking world living in the United States and Hispanics to refer to those living elsewhere. Which means that, by any account, a Latino is also an Hispanic, but not necessarily vice versa." ${ }^{31}$ Here, the relocation of Hispanics to an undefined but clearly non-U.S. elsewhere begs the question why Stavans prefers Hispanic when dealing with U.S. cultural terrains, yet settles for Latino when providing his comic with its title.

One explanation for these apparently shifting and contradictory preferences lies in a fundamental aspect of the Stavans author-function's discursive power: its assumption of 
authority-figure status. Stavans's arbitration of the Latino/Hispanic debate can only be made because everything he says on the matter-in university classrooms, electronic media sound bites, press interviews, essays, books, anthology introductions, a comic — is predetermined by the author-function in expert mode and designed to perpetuate that function. This functional success depends on two factors. First, the expert position implicitly carries the authorizing imprimatur of the author-function's institutional (academic, publishing, media) connections, which in no small part support the production and frame the worldly receptions of the author's texts. Second, expert status is based on the naturalizing premise that the worldly authority it signals will be accepted and respected, not scrutinized.

As it pans out in Latino USA, this usurpation of the expert position also locates the Stavans author-function on one discursive side of the debates over identity terminology. Noriega provides a useful sense of these debates as a struggle between dominant and counterdiscursive interests. Discussing the contradictions and tensions accruing to two terms that ostensibly designate the same populations, he says: “The fact that 'Hispanic' emerges as a U.S. census category suggests the difficult play between race and ethnicity, as the government seeks institutional control through homogenization ('Hispanic'), and social movements undertake radical social change through the formation of a collective identity ('Latino'). ${ }^{, 32}$ Notwithstanding a title that bears the term favored by liberals and radicals, social activists, and many cultural producers and commentators, Latino USA consistently betrays its Author's distance from the counter-discursive option. Latino, and not Hispanic, is preferred by many Latino critics because it avoids the Spanish (Europeanizing) shadow that makes Hispanic the attractive option for community conservatives, U.S. government apparatuses, and the Stavans author-function alike.

The Stavans author-function's stance on the identity question in part supports Noriega and López's argument that since Hispanic and Latino refer to the same sectors, the key issue 
lies in the different political motivations for their deployment. ${ }^{33}$ Yet, as those critics also recognize, all identity categories, including Latino and Hispanic, are subject to epistemological slippage and obfuscate differences. Thus, notwithstanding the issue of political usage, the Latino versus Hispanic conflict is always in danger of being locked into an either/or argument, thus ignoring other axes of dispute and action. Questions arise, then, about Stavans author-function's indefatigable intervention into what Suzanne Oboler calls a "false debate - insofar as, like the label Hispanic, the term Latino or Latina, or even Latin American, does not solve the problems raised by existing national and linguistic, class and racial differences in the U.S. context. ${ }^{\text {34 }}$ Throughout Latino USA those differences are sidelined if not ignored because of the narrative's insistence on deploying potentially antagonistic or inappropriate identificatory options. Latino does not only grate against Hispanic in the narrative; the comic also perpetuates a notion of Latino/Hispanic as by turns a racialized designation, a multinationally vast entity, one that includes Spain among its component parts, and an equally vast linguistic space, el mundo hispanoparlante, in which U.S. Latino specificities may not even count. It is perhaps not uncoincidental that the only historical presence in Latino USA to figure in all of these options is the Author himself, a figuration that again raises the issue of what the Stavans author-function and its worldly referent (the author) might gain from arbitrating Latino and Hispanic in the expansive way it/he does.

\section{Marketing the border-violating Author}

Throughout Latino USA, the iconic Author regards the U.S.-Mexican border as the central spatial and geocultural trope of Hispanic definition, the stress line of cultural clash between Anglo-Saxon and "Spanish"/"Hispanic" Americas. ${ }^{35}$ This may be a valid claim for many Chicanos and some Latin Americans, particularly those, like Stavans, who reside or were 
born in Mexico. But the statement that "The Rio Grande is where Latin America ends and the United States begins" (5) might be disputed by many cubanos, puertorriqueños, and dominicanos in the U.S.A. for whom the U.S.A-Mexico borderline has little, if any, practical or symbolic relevance. In Latino USA, this foregrounding does at least acknowledge the place of Chicanos, the largest Latino sector, in Latino history. Mexican and Chicano cultures receive the greatest attention in terms of historical incidents and cultural references covered. In itself, this Mexican emphasis is unremarkable. It reflects the Mexican-born Author's confident claim to understand Mexican history and cultural currents in a hemispherical context. And it recalls Foucault's argument that a specific writing subject inevitably shadows an author-function, and that texts inevitably contain telling traces of that subject. ${ }^{36}$

Extrapolating from this observation, the U.S.-Mexican border focus in Latino USA suggests that the narrative is not only loaded in favor of the Mexican/Chicano nexus, but of the Author's place in that nexus as well. Stavans's prefatory meditations on Mexican cartoon representations and their impact on his childhood and adolescence in Mexico City provide a case in point. At stake here is not the issue of the homegrown comic's appeal, vitality, and viability as a medium for historical work. The stakes are rather more autobiographical, to do with the way the comic medium has been enlisted to ensure the Author's centrality in a discourse of Latino history that exceeds its U.S. parameters. When considered in relation to the comic's uses of Latino and Hispanic, the constant appearances and references to the Author in the comic suggests that Stavans's own elite Mexican-migrant trajectory into the U.S.A. provides the fundamental basis for an idealized and universal border-crossing Latino experience. That is, Stavans's story — he was born and lived in Mexico City until moving to the U.S.A. in 1985 at the age of 24 , where he went on to complete a doctorate at Columbia University_-functions implicitly as the exemplary model of becoming and being Latino in Latino USA and Stavans's other writings. 
In this respect, Stavans's centrality in his comic history is confirmed by the ways by which the Author of (and in) Latino USA accords himself a heady tripartite function as writer of, commentator on, and (comic) protagonist in history. He is never one mere actor or character in a larger theatrical-cum-historical cast, as the Toucan puts it (164). As sideline commentator, the Author asserts his literary credentials - learned in Mexico, and consolidated in the U.S. academy—at every possible opportunity, even to the point of dismissing as “simplistic” criticisms of Octavio Paz's 1950 study of the Mexican national character, El laberinto de la soledad, for its denigrations of Pachucos (91). ${ }^{37}$ More interesting, however, are the many scenes that feature the Author as political activist and agent of change, a transhistorical role facilitated by his temporal and geopolitical bordercrossing comic powers. He is bundled into a police car at the Sleepy Lagoon incident in Los Angeles, 1942, a key moment in the formation of a politicized Chicano consciousness (88). He appears in a panel dedicated to the Chicano Movement's links to the anti-Vietnam War struggle, wearing a Brown Beret as if he were not only actually involved, but a central player in that struggle (120). He lurks in the shadows at the National Chicano Moratorium in Los Angeles in 1970, again implying his radical participation. He is depicted swimming in Havana harbor on his way to exile in Miami, a paradigmatic victim of Castro's “intolerance of opposing political views" (140). But perhaps the most illuminating image immediately follows a panel that presents Chicano historian's Rodolfo Acuña's critique of the Latino middle classes in the 1980s who, driven by the dream of "making it," "forgot their class roots" (138). The next panel shows the Toucan and the Calavera discussing Acuña's thesis, with the Calavera expounding on the Spanish phrase, "hacerla en el sueño americano" [making it in the American Dream]. Meanwhile, at the right-hand edge of the panel, the Author, the happy recipient of a massage, snoozes under a sign containing an arrow that points to the right, and the bilingual, undoubtedly ironic, message: "Exito/Success" (138). 
The Author's appearances in Latino USA as the ubiquitous Latino social activist imply, if not his actual involvement in civil rights struggles, his real-world leftist allegiances. But this particular scene is also legible as a sign of other successes: first, his "making it" in the American Dream at the expense of the Latino have nots; and second, his reformulation of Latino history and discourse so they are unimaginable without him.

This reading is supported by the comic's transformation of Stavans into the literal embodiment of the Latin American romance of a united, democratic "Hispanic America." In a sense, while all of the Author's appearances in Latino USA work toward and reinforce a happy dream of transnational, border-dispensing unity as the central tenet of a broadly applicable latinidad, the ambition is explicit in some panels. For instance, the Author is shown upholding the "spirit of comradeship, of unity against the menacing U.S. foreign policies" that apparently overcame the "Hispanic world" after the 1929 Wall Street crash (72). His embodiment of the "Hispanic" romance attains its apogee when Latino USA enters the 1980s, "the decade of panethnic relations" (150). Simón Bolivar, architect of Latin American nation building, is introduced to explain his dream "of "The United States of Latin America,' a republic made of Hispanics of all different backgrounds" in direct opposition to the U.S.A., and to express his astonishment that the dream has now been "realized within Los Estados Unidos" (150). In the preceding panel illustrating this fictive apotheosis, Stavans, with his "beautiful señorita" in tow, centers what the accompanying text defines - against the views of most Latino commentators - as the history-making emergence of Latinos as a fully fledged, conceptually coherent, and firmly united entity.

Modulating these ambitions is the Author's desire, articulated in the Foreword, to construct a narrative that combines "the solemnity of so-called serious literature and history with the inherently theatrical and humorous nature of the comics" (xiv). This ambition to mutually contaminate high and low cultural capital, however, is belied by the questions posed 
by Stavans in his other authorial function as indefatigable anthologist: "the fact that anthologies can be canon-makers gave me pause. How does one craft the canon of people who are only beginning to be perceived as a group?"38 The framing of this question confirms that for Stavans, the canon that identifies and coheres an imagined collective such as Latinos is predicated on literary texts. The realm of the popular has no real place in the processes by which the "group" perceives itself. A similar conclusion can be drawn from Latino USA. The comic medium provides a visually enhanced and attractive venue - a popular-cultural framework - in which Stavans can provide Latinos with the "high" cultural icons they might otherwise lack, or be unaware of. Thus, while mass-cultural references are to be found in the comic history, high-cultural, mostly literary, references dominate its intertextual traffic.

Stavans makes passing mention of the usual crop of big-name Latino and Latina authors (Sandra Cisneros, Julia Álvarez, Richard Rodriguez, Oscar Hijuelos) who have achieved mainstream success. He also refers to literary figures from the Latino past, such as the Chicano Oscar "Zeta" Acosta and the Puerto Rican Julia Burgos. But the majority of writers named in Latino USA derive from outside the Latino canon. To mention some examples, Borges, Kafka, Neruda, Darío, Rodó, and Cervantes all make intertextual appearances. In many cases, the inclusion of writers is predicated on Stavans's own publishing or personal relation to the authors concerned. Despite his sideline comment that Cabeza de Vaca's memoir of shipwreck is "a bad book if I may say so" (15), Stavans also supplied the introduction to the new Penguin Classic edition of that sixteenth-century text. ${ }^{39}$ Felipe Alfau, the Spanish migrant whose Sentimental Songs was translated by Stavans, is accorded honorary Latino status. ${ }^{40}$ Acosta receives a page-and-a-half of attention in Latino USA; but the clue to this generosity is provided by the (supposedly ironic) words "Shameless plug!" that the Cartoonist has left above the Author as he reads Bandido, Stavans's study of 
Acosta's life and works (127). ${ }^{41}$ Richard Rodriguez's Hunger of Memory gets an endorsement — "The prose is superb—rhythmic, persuasive" (144) — that mirrors Rodriguez's enthusiasm for Stavans on the book's back cover.

Related to these "plugs" is the text's championing of Spanglish, as might be expected from an author who has cast himself in the role of defender and popularizer of that idiom in the U.S.A. (14). ${ }^{42}$ Interestingly, while the championing of Spanglish is one of the hallmarks of the Stavans author-function, Latino USA withholds from making Spanglish its lingua franca. The comic's gestures toward linguistic admixture stop with a little code switching, and some interruptions of its predominant English by Spanish words. In the comic, the defense of Spanglish is accompanied by a panel image of an unidentified Yale academic bemoaning the inroads that Spanglish is making in the United States: "Did you say Dictionary of Spanglish — that impure mixture of English and Spanish? No, no, no, no, we should teach our students to speak 'proper' languages not dialects" (14). The academic in question is Roberto González Echevarría, a vigorous opponent of Spanglish and its supporters. As he said in 1997, "Spanglish treats Spanish as if the language of Cervantes, Lorca, García Márquez, Borges and Paz does not have an essence and dignity of its own."

There is a certain irony in the way that Stavans's support for Spanglish puts him at loggerheads with González Echevarría. The Stavans author-function constantly evokes Cervantes, Lorca, García Márquez, Borges, and Paz in order to add "high-cultural" weight to his interventions in Latino Studies; many of these writers are mentioned in Latino USA as "Latino" literary forebears. The discursive situations of Stavans and González Echevarría are thus more alike than either figure would admit. It should be noted, too, that Stavans is at home equally in the languages of Shakespeare and Cervantes. He switches easily between them, and Spanglish. But this optional use of Spanglish would distinguish him from, for 
instance, a hypothetical cholo from East L.A. for whom Spanglish is the only available idiom, thereby locking that person into a linguistic scenario that precludes shifting between different class and social settings.

The internalized autobiographical references - a barrage of product placements - in Latino USA do not simply cement the impression that the comic has provided the Author with a neatly eye-catching format by which to further advance a "professional career [based] on the muses of literature and academia" (xiv). Beyond that commercial function, the central place allocated to the author's academic and publishing interests and outputs also impacts on the text's stated aim to chart the history and civil rights' struggles of the U.S.A.'s diverse Latino populations. For instance, the comic's treatment of Richard Rodriguez's first volume of autobiography, Hunger of Memory, is emblematic of the way by which important debates in Latino Studies are disarmed or sidestepped in Stavans's version of Latino history. ${ }^{44}$ In the panel to the right of Stavans's endorsement of Rodriguez's text, the Cartoonist is shown poking a finger into his mouth, and wearing a t-shirt that says “Absence of Memory”(144). This alludes to the widespread criticisms of Rodriguez's book for supporting assimilationist policies and endorsing the inevitability and necessity of de-Mexicanization as the children of Mexican immigrants learn English and embrace the values of Anglo-American mainstream culture. Like the Cartoonist's implied disagreement with the Author over Hispanic/Latino, the scene iterates the political tensions between the two icons in the comic, one progressive, the other conservative. But the narrative does not explore why those tensions might matter, or what they have entailed in Chicano civil rights struggles or Latino Studies criticism alike; it is left to readers to decode such disputes as a species of in-joke. Moreover, the comic here reduces the political controversy over Rodriguez's autobiography to an ahistorical argument over aesthetics and style. 


\section{The alibi of intellectual cosmopolitanism}

Stavans has characterized his popularizing mission in these terms: "I write in English for Americans about topics they know little about, and I write in Spanish for Mexicans about topics they are unacquainted with. I act as a bridge, I symbolize dialogue . . . I am the owner of a divided self and am sure that my circumstances come as a result of exile and, also, of a polyglot existence." ${ }^{45}$ Left undefined in this confession of altruism, and in the Author's comments about his hopes for his comic as well, is the make-up of his intended audience. In the case of Latino USA, a U.S. readership is perhaps the comic history's obvious beneficiary; but this audience could mean, variously, school-children, Latinos of all ages, AngloAmericans of all ages, Latinos and Anglos alike, other academics, or perhaps an imagined coterie of regular readers in thrall to the Author's penchant for littering his texts with selfreferential clues. That said, the comic's hard-cover presentation and cost, US\$20, as well as its decidedly high-cultural internal references that require a certain level of reader familiarity, suggest a highly educated and economically privileged readership, one that cannot be aligned with the ranks of comic consumers in both the U.S.A. and Latin America where comics are mass-produced and affordable. Yet with no clear parameters for identifying precisely its audience, the impression arises that Latino USA was conceived, produced, and sent out into the world as if its lot were transcendental homelessness, to borrow Heidegger's formulation. Perhaps the comic was intended for all readers, for all inhabitants of Stavans's "planetary city," in keeping with the author's didactic bridging aspirations.

Stavans's self-anointed bridging function is presented as if no other Mexican or "American," Latino or otherwise, has ever attempted a dialogue, or indeed attempted to do the comic work that Latino USA purports to do. A case in point, and a highly apposite one given that it was the first comic-book account of Chicanos, is The Chicanos, a text dating from 1973 by the Mexican cartoonist Rius. ${ }^{46}$ Produced by the North American Congress on 
Latin America (NACLA), The Chicanos is an updated translation into English of the original Spanish-language comic in Rius's "Los Agachados" series, from Editorial Posada. As with much of Rius's work, and as its foreword indicates, The Chicanos is informed by a leftist political agenda that targets the U.S. "government and its imperialist policies." Interestingly, it also advocates a trans-border alliance between Mexican workers and intellectuals and the Chicano workers in the north. The Chicanos is self-consciously didactic and, like Latino USA, utilizes recurring characters and icons to construct its historical narrative of gringo exploitation and Chicano victimization at the hands of bosses and state agents alike. Although Stavans refers to Rius in the foreword to Latino USA as an important forerunner of his own comic history, he does not mention The Chicanos as either a significant antecedent or influence.

One possible explanation for this oversight, and for Stavans's self-conscious assumption of a pan-American bridging role that overlooks prior dialogues and cultural productions, might lie in the Author's figuration of himself, using V. S. Naipaul's terminology, as an exile, a "man of no tribe. ${ }^{, 47}$ This variant of transcendental homelessness provides the Author with an ambivalent, yet productive, location: "it [exile] can give you freedom; you don't have to be loyal to a set of symbols, to patriotic concepts. On the other hand, you will retain a sense of loss: everyone else belongs somewhere. ${ }^{, 48}$ But the logic here is disingenuous. Casting himself, and his texts, into that amorphous place of potential and pain called exile, Stavans glosses over his unequivocal homeliness in U.S. academic and publishing apparatuses, the bases from which he projects his writings into the wider "Hispanic" world, and inserts himself into the terrains of U.S. Latino culture as its chief advocate. The Stavans author-function thus resonates from textual into material-world terrains, with Stavans himself emerging, to cite Caren Kaplan, as an exemplary “cosmopolitan intellectual or writer ... proclaiming liberation politics from the safety zone 
of privilege, traveling to accrue and control knowledge in the name of [Hispanic]

multiculturalism." ${ }^{49}$ As if to underscore the uncontroversial, comfortable, and state-friendly coordinates of his "exile" in the United States, the Author appears in the Epilogue to Latino USA waving Mexican and U.S. flags, while a conversation balloon proclaims, "America, America sweet land of liberty!"' (159). It is a heavily ironic scene, but perhaps not in the way the Author imagined.

The discursive situation by which the Stavans author-function appears as "el zar" [the tsar] of Latino culture, to use a description from the Spanish newspaper El Pais, ${ }^{50}$ reflects, in the Foucauldian sense, a will to appropriate a "transdiscursive" role as the "initiator" of Latino discursive practices. ${ }^{51}$ This move to founding-father status clearly surpasses the author-function's more modest brief "to characterise the existence, circulation, and operation of certain discourses within a society." ${ }^{, 52}$ In Latino USA and other Stavans-penned texts, the omnipresent Stavans author-function dispenses a self-legitimating version of both the Latino identification he occupies despite exile, and the field of Latino Studies he popularizes and centers. Stavans, in effect, subsumes lo latino into the cosmopolitan romance of a pax latinoamericana, with its origins and dominant logics anchored in a Spanish (national, literary, linguistic, gendered) patrimony. In this romance, geopolitical borders, and class, racial and gender/sexual divides, offer few obstacles. His discursive situation so sanctioned, the Stavans author-function finds its modus operandi and authorial alibi. Since his true discursive home is intellectual cosmopolitanism-cum-exile, Stavans never need explain his post-European, postMexican residency as the endgame result of a move by a Mexican-trained critic to a more lucrative and institutionally powerful seat in the U.S. academy. Lost in this dissembling approach to his personal trajectory are the historical-material benefits that derive from the Author's interventions in the highly charged terrains of Latino cultural politics. Stavans 
generates his texts as if his physical, institutional and discursive mobility does not confirm the separation of his cosmopolitan world from that of the Latino millions who have yet to find solace, safety or security in the romance he popularizes. Stavans never admits that in order to pronounce authoritatively on a broad Latino habitus he must expand the conceptual edges of "Latino," or better Hispanic, into exclusive cosmopolitan territory so that his migrating-academic self can slip unquestioned into it.

Latino USA's back cover suggests, in principle, that these matters do preoccupy the Author: "Will all taco lovers please stand up? There's no doubt about it, Latinos are a social force rapidly revolutionizing the texture of America, but who are they? A single homogenized group or a sum of minorities? Are they all linked through a common language and ancestry?" But Latino USA sidesteps answering these fundamental questions. The comic confirms the Author's failure to sustain a desimplified transnational and transcultural understanding of "Latino" even as he expands that designation into planetary terrain. And the narrative takes up the tropicalizing spirit of the "taco lover" reference to perpetuate a consistently clichéd reading of lo latino. More to the Stavansian point, the back-cover questions are framed by sound bites of "Praise for Ilan Stavans," which laud him as the trailblazer of Latino Studies. Readers encounter renowned García Márquez translator, Gregory Rabassa, holding a tome entitled "100 years of Ilan Stavans" while approving Stavans's "grip" on "Spanish America." Readers perceive an endorsement of Stavans's “opening [of] the door" on "Hispanic culture" from the Spanish newspaper El País. They are met by Chicana Kathleen Alcalá's claims that Latino USA might even provide the antidote to a century-and-a-half of Anglo-U.S. accounts of the Alamo, and similar claims about Stavans's "giant leap forward in setting the record straight" from Colombian-born Jaime Manrique. And readers are presented with the fulsome commendation of Stavans's friend and "Hispanic" ally, Richard Rodriguez, for whom Stavans is the border-violating intellectual par 
excellence, the heir to Octavio Paz, despite that particular intellectual's concerned dismissal of Mexican-Americans as irredeemably abject. Forgotten in this catalogue of praise are the many Latino cultural producers and critics who, over many decades, have labored to set the Latino historical "record straight." This figuration of Stavans as the inventor of a "new," never before countenanced, Latino purview has obvious implications for the selected Latino cultural producers and critics whose viewpoints he mediates and samples in Latino USA.

The defining characteristic of the Stavans author-function would seem to be an indifference to its inhabitation of an epoch that has come to distrust, in Foucauldian terms, the intellectual who "place[s] himself 'somewhat ahead and to the side' in order to express the stifled truth of the collectivity," in this case the stifled imagined Latino collectivity. ${ }^{53}$ In the conversation with Gilles Deleuze in which Foucault's stand against this breed of intellectual appears, Foucault offers some suggestions for a critical project that not only refuses to regard the intellectual as self-designated arbiter of truth, but heeds Deleuze's warning about "the indignity of speaking for others" (209). The only viable critical agenda is to "struggle against the forms of power that transform him [the intellectual] into its object and instrument in the sphere of 'knowledge,' 'truth,' 'consciousness,' and 'discourse'” (208). The critic's task is to identify and thus begin to sabotage — by "denouncing and speaking out"the myriad ways by which intellectuals may come to dominate speech and benefit from exclusive discursive positions. The intellectual author-function thus requires careful scrutiny precisely because of its often unremarked and unremarkable power-generating capacities. Indeed, to cite Edward Said here, such scrutiny of the author-function and its writing-subject shadow must accredit "the self-confirming will to power from which many texts can spring." ${ }^{, 54}$ This, then, might be the appropriate response when readers of Latino USA confront the Stavans author-function as it violates borders, moves in cosmopolitan mode in safe U.S. “exile," presumes to speak regardless for all Latinos, and takes refuge in "innocent" comic 
play. These discursive sleights of hand invite "all taco lovers" (and critical allies) to take the first step in reversing the power that has named them as such, and then inscribed them into the comic "fiesta of types, archetypes, and stereotypes" that is Stavans-centered Latino history.

\section{Acknowledgements}

I would like to thank Lyn Shoemark for her listening ear and intuitive suggestion during a fraught week in the writing of this essay. Gratitude is also due to Trish Hill for her patient reading and comments, and to Murray Pratt for his astute attentions to the discursive situation of, and comic vocabulary used in, my analysis. For their discussion of an earlier version of this paper, I would also like to thank Diana Palaversich and the other participants in the Workshop on "The Death of the Concerned Intellectual," organized by Feng Chongyi at the Institute for International Studies, University of Technology, Sydney, Australia, in December 2002. 
${ }^{1}$ Ilan Stavans, Latino USA: A Cartoon History, with illustrations by Lalo Alcaraz (New York: Basic Books, 2000). Further references to this text are indicated in parentheses.

${ }^{2}$ Ariel Dorfman and Armand Mattelart, How to Read Donald Duck: Imperialist Ideology in the Disney Comic, trans. David Kunzle (New York: International General, 1991).

${ }^{3}$. The university in question is Amherst College, Massachusetts. The course in Spanglish administered and taught by Stavans was introduced in 2000. For elaborations of Stavan's interest in the idiom see: Spanglish: The Making of a New American Language (Rayo: New York, 2003); "Spanglish: Tickling the Tongue," World Literature Today 74 (2000): 555-58; and "The Gravitas of Spanglish," Chronicle of Higher Education 47 (13 October 2000): B710 .

${ }^{4}$. Among Stavans's many publications are The Hispanic Condition: Reflections on Culture and Identity in America (New York: Harper, 1995), an overview of U.S. Latino cultures, and the essay collection, The Essential Ilan Stavans (New York and London: Routledge, 2000). Stavans is also a prolific anthologizer.

${ }^{5}$ Foucault, Michel, "What is an Author?," in Language, Counter-Memory, Practice: Selected Essays and Interviews, ed.. Donald F. Bouchard, trans. Donald F. Bouchard and Sherry Simon (Ithaca: Cornell University Press, 1977): 124.

${ }^{6}$ Foucault, "What is an Author?," 129.

${ }^{7}$ Foucault, "What is an Author?," 138.

${ }^{8}$ Edward Said, "The World, the Text, and the Critic," in The World, the Text, and the Critic (London: Vintage, 1991 [1983]), 50.

${ }^{9}$ Scott McCloud, Understanding Comics: The Invisible Art (Northhampton, MA: Kitchen Sink Press, 1993), 9.

${ }^{10}$ Alcaraz is one of the most interesting and politically engaged cartoonists in the U.S.A., and an important chronicler of, and for, west-coast Chicano communities. As the biographical page ("Meet Lalo Alcaraz") at Ucomics.com iterates, Alcaraz's influence and reputation have been cemented by the artist's multiple ventures over many years. These include regular editorial cartoons in the LA Weekly, syndicated contributions to a host of other newspapers across the U.S.A., film animation credits, and co-editorship of the consistently biting and hilarious Pocho magazine (www.pocho.com).

11 Martin Barker, Comics: Ideology, Power and the Critics (Manchester and New York: Manchester University Press, 1989), 133.

12 This qualification does not deny that the Stavans author-function may occupy what Foucault calls "a variety of egos" and "subjective positions" (Foucault, "What is an Author?," 130). For example, one feature of the Stavans author-function not addressed here 
for reasons of space is his fictional, critical, and editorial interest in the Jewish contribution to Latin American culture and literature. He is also a critic of Jewish literature more broadly. See, for example, his edited volumes Tropical Synagogues: Short Stories by Jewish-Latin American Writers (New York: Holmes and Meier Publishers, 1994), and The Oxford Book of Jewish Stories (Oxford: Oxford University Press, 1998), his short-story collection The OneHanded Pianist (Albuquerque: University of New Mexico Press, 1996), and the essay anthology The Inveterate Dreamer: Essays and Conversations on Jewish Culture (Lincoln: University of Nebraska Press, 2001).

${ }^{13}$ Chon A. Noriega, "El hilo latino: Representation, Identity and National Culture," Jump Cut 38 (1993): 46.

${ }^{14}$ Frances R. Aparicio, "Reading the 'Latino' in Latino Studies: Toward Re-imagining Our Academic Location," Discourse 21 (Fall 1999): 4.

${ }^{15}$ Mikhail Bakhtin, The Dialogic Imagination: Four Essays, trans. Caryl Emerson and Michael Holquist (Austin: University of Texas Press, 1981).

${ }^{16}$ Foucault, "What is an Author?," 137.

${ }^{17}$. One notable indigenous absence is la Malinche, Cortés's slave, "consort," and translator, and a central figure in the Spanish conquest of the Aztecs. The subject of feminist revisions by numerous Mexican and Chicana writers, her presence in Latino USA might have helped to push against the Euro-frame on which its historical trajectory relies, despite the Author's stated anti-Eurocentrism in the Foreword. Sor Juana Inés de la Cruz, perhaps the most important Latin American writer of the colonial era, is also overlooked.

${ }^{18}$. For example, these "what if?" inversions of the European "discovery" of the New World appear in many performance works by Guillermo Gómez-Peña. And they are a favorite topic of conversation among the combatants in Alfredo Véa's novel about the Vietnam War, Gods Go Begging (New York: Dutton, 1999). Coincidentally, a recurrent question in the novel, "Do you suppose that there will ever be Mexicanos in space?" (109), appears in similar form in the third section of Latino USA, in a panel depicting a space rocket marked with the words "US of Aztlán," and, as astronauts, the Author and the Calavera, the latter of whom asks: "Wouldn't it be cool to have a Chicano en la luna [on the moon]?" (122). The "what if" scenario is a pet trope in many of Stavans's texts. But in at least one instance the trope's source is unacknowledged: the line "What if yo were you and tu fueras I, Mister?" from The Hispanic Condition (7), does not accredit Gómez-Peña's performance poem, "Califas," in which the identical wording originally appeared (Warriors for Gringostroika: Essays, Performance Texts, and Poetry [Saint Paul: Greywolf, 1993], 71). At the very least, this example supports the Calavera's argument with the Toucan that very few texts "are truly original" (59).

${ }^{19}$. Other resonances accrue to this scene. In July 2002, Stavans published his Spanglish translation of Part one of Don Quijote in the Spanish newspaper La Vanguardia. The translation is reprinted in his Spanglish: The Making of a New American Language, 251-58.

${ }^{20}$ Stavans, Hispanic Condition, 200. 
${ }^{21}$ Noriega, "El hilo latino," 47.

${ }^{22}$ Stavans's use of the "sleeping giant" metaphor comes from his essay "Hispanic USA," The American Prospect 4 (21 September 1993), accessed 19 April 2002, www.prospect.org/printfriendly/V4/15/stavans-i.html.

${ }^{23}$. In 1897, acceding to pressure from the island's bourgeoisie, Spain passed a Charter of Autonomy that granted its island colony a limited form of home rule under a Spanish governor, with its own bicameral legislative assembly, the right to representatives in the Spanish Cortes, and decision-making powers over trade matters. The Charter might have lead to Puerto Rico's eventual independence but that option was precluded by the SpanishAmerican War in 1898, which resulted in the annexation of the colony by the U.S.A. See Lila Perl, Puerto Rico: Island Between Two Worlds (New York: William Morrow, 1979), 48-49, and Iris M. Zavala, "Introduction," in The Intellectual Roots of Independence: An Anthology of Puerto Rican Political Essays, eds. Iris M. Zavala and Rafael Rodríguez (New York: Monthly Review Press, 1980), 20. While not wishing to belabor the point, it needs to be noted that a laissez faire approach at best characterizes Stavans's grasp of history in much of his published output. In Spanglish, for example, Stavans casually mentions "the arrival of democracy in [Spain in] in 1974," one year before General Franco's death (31). Similar slips led noted Octavio Paz scholar Eliot Weinberger to deliver a devastating expose of the factual errors littering Stavans's writings on the Mexican poet ("Paz as 'Dictator': A Response to Ilan Stavans," Transition 63 (1994): 120)

${ }^{24}$ Frances R. Aparicio and Susana Chávez-Silverman, "Introduction," in Tropicalizations: Transcultural Representations of Latinidad, eds. Frances R. Aparicio and Susana ChávezSilverman (Hanover, NH: University Press of New England, 1997), 1.

${ }^{25}$ Barker, Comics, 131.

26. This claim is of note for subsuming Puerto Ricans and Cubans, residents of Spain's last New World colonies, under the Spanish rubric, and ignoring residents of the northern half of Mexico, ceded to the U.S.A. in 1848. The 1853 date exemplifies the arbitrary approach to time in the narrative, and does not sit easily with the text's many statements that 1848 is the year when Latino U.S.A. was inaugurated.

${ }^{27}$. Questions 5 of the 2000 Census asks "Is this person Spanish/Hispanic/Latino?," while Question 6 asks that person to identity his/her race according to a range of options (Elizabeth M. Grieco, and Rachel C. Cassidy, "Overview of Race and Hispanic Origin: Census 2000 Brief," U.S. Census Bureau, Washington, March 2001: 1). Respondents could also nominate more than one racial category, the Census in theory thus permitting identifications along mixed race lines. For a sustained analysis of the impact of U.S. Census Bureau definitions on Latino identity debates see Clara E. Rodríguez, Changing Race: Latinos, the Census, and the History of Ethnicity in the United States (New York: New York University Press, 2000). For excellent accounts of Hispanic/Latino identity struggles and debates, and their relation to U.S. racializing discourses, see Suzanne Oboler, Ethnic Labels, Latino Lives: Identity and the Politics of (Re)Presentation in the United States (Minneapolis and London: University of Minnesota Press, 1995), and Arlene Dávila, Latinos, Inc.: The Marketing and Making of a 
People (Berkeley: University of California Press, 2000).

28 "Entrevista con Ilán Stavans," in Cuadernos Cervantes (N.d.), Archivo CC 31, accessed 19 April 2002, www.cuadernoscervantes.com/entrevilanstavans.html.

${ }^{29}$ Stavans, "Hispanic USA," 3.

${ }^{30}$ Stavans, "The Writer in Exile: Interview," Web del Sol (N.d.), accessed 19 April 192001 , www.webdelsol.com/istavans/is-in.html.

${ }^{31}$ Stavans, The Hispanic Condition, 27.

${ }^{32}$ Noriega, "El hilo latino," 46.

${ }^{33}$ Chon A. Noriega, and Ana M. López, "Introduction," in The Ethnic Eye: Latino Media Arts, eds. Chon A. Noriega and Ana M. López (Minneapolis: University of Minnesota Press, 1996), xi.

${ }^{34}$ Oboler, Ethnic Labels, Latino Lives, 165.

35. The unhelpfulness of "Hispanic" or "Spanish America"- a term that appears on Latino USA's back-cover as well - when not restricted to the colonial era and very carefully qualified, is demonstrated by making an analogy with "English America." That expansive option, which might include the U.S.A., much of Canada, Guyana, many Caribbean island states, Belize, and even the English-Creole speaking pockets on the Atlantic coasts of Nicaragua and Costa Rica, has no currency.

${ }^{36}$ Foucault, "What is an Author?," 129

${ }^{37}$ See "El Pachuco y otros extremos," in El laberinto de la soledad. Postdata. Vuelta a El laberinto de la soledad, 3a ed. (México: Fondo de Cultura Económica, 1999 [1950]), 11-31.

${ }^{38}$ Stavans, "The Quest for a Latino Literary Tradition," Chronicle of Higher Education 47 (1 December 2000), accessed 16 January 2001, chronicle.com/free/v47/i14/14b01301.htm.

${ }^{39}$ Alvar Núñez Cabeza de Vaca, Chronicle of the Narvaez Expedition, rev. Harold Augenbraum, intro. Ilan Stavans (New York: Penguin Classics, 2002).

${ }^{40}$ Felipe Alfau, Sentimental Songs: La Poesia Cursi, trans. Ilan Stavans (McLean, IL: Dalkey Archive Press, 1992).

41. Stavans, Bandido: Oscar "Zeta" Acosta and the Chicano Experience (Boulder: Westview Press, 1995). Stavans is also editor of Oscar "Zeta" Acosta: The Uncollected Works (Houston: Arte Público Press, 1996).

42. In the frame, the Author invites readers to consult a dictionary of Spanglish, which was being widely advertised at the time of the publication of Latino USA with the title Spanglish: An Illustrated Lexicon, under the New York-based Basic Books imprint. That particular 
publication has not appeared, but a glossary of Spanglish is included in Stavans's Spanglish: The Making of a New American Language.

${ }^{43}$ Roberto González Echevarría, "Is Spanglish a Language?," New York Times (28 March 1997), accessed 16 May 2002, www.nytimes.com/yr/mo/day/oped/28gonz.html.

${ }^{44}$ Richard Rodriguez, Hunger of Memory (New York: David R. Godine, 1982).

${ }^{45}$ Stavans, "The Writer in Exile."

${ }^{46}$ Rius, The Chicanos (Berkeley: NACLA, 1973). My thanks to Diana Palaversich for bringing this comic to my attention. In his Preface, Stavans provides a possible explanation for not mentioning this particular text when he states: "I stopped reading Rius one specific day, when a most anti-Semitic installment of Los agachados, endorsing Hitler, reached my hand" (xii).

47. Stavans, "The Writer in Exile." Also informing this claim to exile status is Stavans's Jewish background, and his family's displacement from Europe to the Jewish quarter of Mexico City where Stavans was born ("The Writer in Exile").

48 . Stavans, "The Writer in Exile."

${ }^{49}$ Caren Kaplan, Questions of Travel: Postmodern Discourses of Displacement (Durham and London: Duke University Press, 1996), 126.

${ }^{50}$ Juan A. Carbajo, "El mundo hispánico hablaré Spanglish,” El País, (2 enero 2000): 34 (sección cultura).

${ }^{51}$ Foucault, "What is an Author?," 131.

${ }^{52}$ Foucault, "What is an Author?," 124.

${ }^{53}$ Michel Foucault, "Intellectuals and Power: A Conversation Between Michael Foucault and Gilles Deleuze," in Language, Counter-Memory, Practice: Selected Essays and Interviews, ed. Donald F. Bouchard, trans. Donald F. Bouchard and Sherry Simon (Ithaca: Cornell University Press, 1977), 208.

${ }^{54}$ Said, "The World, the Text, and the Critic," 50.

\section{Works Cited}

Acosta, Oscar "Zeta." 1996. Oscar "Zeta” Acosta: The Uncollected Works, ed. Ilan Stavans. Houston: Arte Público Press.

Alfau, Felipe. 1992. Sentimental Songs: La Poesia Cursi. Translated by Ilan Stavans. McLean, IL: Dalkey Archive Press.

Aparicio, Frances R. 1999. "Reading the 'Latino' in Latino Studies: Toward Re-imagining Our Academic Location.” Discourse 21.3 (Fall): 3-18. 
Aparicio, Frances R., and Susana Chávez-Silverman, eds. 1997. Tropicalizations: Transcultural Representations of Latinidad. Hanover, NH: University Press of New England.

Bakhtin, Mikhail. 1981. The Dialogic Imagination: Four Essays. Translated by Caryl Emerson and Michael Holquist. Austin: University of Texas Press.

Barker, Martin. 1989. Comics: Ideology, Power and the Critics. Manchester and New York: Manchester University Press.

Cabeza de Vaca, Alvar Núñez. 2002. Chronicle of the Narvaez Expedition. Rev. Harold Augenbraum. Intro. Ilan Stavans. New York: Penguin Classics.

Carbajo, Juan A. 2000, "El mundo hispánico hablaré spanglish.” El País (sección cultura) (2 enero): 34.

Dávila, Arlene. 2000. Latinos, Inc.: The Marketing and Making of a People. Berkeley: University of California Press.

Dorfman, Ariel, and Armand Mattelart. 1991 [1971]. How to Read Donald Duck: Imperialist Ideology in the Disney Comic. Translated by David Kunzle. New York: International General.

Foucault, Michel. 1977. "Intellectuals and Power: A Conversation Between Michael Foucault and Gilles Deleuze." In Language, Counter-Memory, Practice: Selected Essays and Interviews, ed. Donald F. Bouchard. Translated by Donald F. Bouchard and Sherry Simon, 204-17. Ithaca: Cornell University Press.

--- . "What is an Author?” In Language, Counter-Memory, Practice: Selected Essays and Interviews, ed. Donald F. Bouchard, trans. Donald F. Bouchard and Sherry Simon, 11338. Ithaca: Cornell University Press.

Gómez-Peña, Guillermo. 1993. Warriors for Gringostroika: Essays, Performance Texts, and Poetry. Saint Paul: Greywolf Press.

González Echevarría, Roberto. 1997. “Is Spanglish a Language?” New York Times, 28 March, Accessed 16 May 2002. www.nytimes.com/yr/mo/day/oped/28gonz.html

Grieco, Elizabeth M., and Rachel C. Cassidy. 2001. "Overview of Race and Hispanic Origin: Census 2000 Brief." U.S. Census Bureau, Washington, March: 1-11.

Kaplan, Caren. 1996. Questions of Travel: Postmodern Discourses of Displacement. Durham and London: Duke University Press.

McCloud, Scott. 1993. Understanding Comics: The Invisible Art. Northhampton, MA: Kitchen Sink Press.

“Meet Lalo Alcaraz.” N.d. Biographical page. Ucomics.com. Accessed 16 May, 2002. www//ucomics.com/laloalcaraz/bio.phtml

Noriega, Chon A. 1993. "El hilo latino: Representation, Identity and National Culture." Jump Cut 38: 45-50.

Noriega, Chon A., and Ana M. López, eds. 1996. The Ethnic Eye: Latino Media Arts. Minneapolis: University of Minnesota Press.

Oboler, Suzanne. 1995. Ethnic Labels, Latino Lives: Identity and the Politics of (Re)Presentation in the United States. Minneapolis and London: University of Minnesota Press.

Paz, Octavio. 1999 [1950]. El laberinto de la soledad. Postdata. Vuelta a El laberinto de la soledad, 3a ed. México: Fondo de Cultura Económica.

Perl, Lila. 1979. Puerto Rico: Island Between Two Worlds. New York: William Morrow.

Rius. 1973. The Chicanos. Berkeley: NACLA.

Rodríguez, Clara E. 2000. Changing Race: Latinos, the Census, and the History of Ethnicity in the United States. New York: New York University Press. 
Rodriguez, Richard. 1982. Hunger of Memory: The Education of Richard Rodriguez, An Autobiography. New York: David R. Godine.

Said, Edward. 1978. Orientalism. London: Routledge \& Kegan Paul.

--- . 1991 [1984]. The World, the Text, and the Critic. 1984. London: Vintage.

Stavans, Ilan. N.d. "Entrevista con Ilan Stavans." Cuadernos Cervantes, Archivo CC 31. Accessed 19 April 2002. www.cuadernoscervantes.com/entrevilanstavans.html

----. N.d. “The Writer in Exile: Interview.” Web del Sol. Accessed 19 April 2002. www.webdelsol.com/istavans/is-in.html

--- . 1993. "Hispanic USA." The American Prospect 4.5 (21 September). Accessed 19 April 2002. www.prospect.org/print-friendly/V4/15/stavans-i.html

--- . ed. 1994. Tropical Synagogues: Short Stories by Jewish-Latin American Writers. New York: Holmes and Meier Publishers.

--- . 1995. Bandido: Oscar "Zeta" Acosta and the Chicano Experience. Boulder: Westview Press.

--- . 1995. The Hispanic Condition: Reflections on Culture and Identity in America. New York: Harper.

--- . 1996. The One-Handed Pianist. Albuquerque: University of New Mexico Press.

--- . 2000. The Essential Ilan Stavans. New York and London: Routledge.

--- . 2000. "The Gravitas of Spanglish." Chronicle of Higher Education 47.7 (13 October):

B7-10. Accessed 19 April 2002. chronicle.com/free/v47/i07/07b00701.html

--- . 2000. Latino USA: A Cartoon History. Illustrated by Lalo Alcaraz. New York: Basic Books.

--- . 2001. The Inveterate Dreamer: Essays and Conversations on Jewish Culture. Lincoln: University of Nebraska Press.

---- ed. 2002. The Cross and the Scroll: A Jewish-Hispanic Reader. New York: Routledge.

--- . 2000. "The Quest for a Latino Literary Tradition." Chronicle of Higher Education 47.14

(1 December): B13-15. Accessed 16 January 2001.

chronicle.com/free/v47/i14/14b01301.htm

--- . 2003. Spanglish: The Making of a New American Language. Rayo: New York.

--- . 2000. "Spanglish: Tickling the Tongue." World Literature Today 74: 555-58.

Véa, Alfredo. 1999. Gods Go Begging. New York: Dutton.

Weinberger, Eliot. 1994. "Paz as 'Dictator': A Response to Ilan Stavans," Transition 63: 12025.

Zavala, Iris M. 1980 "Introduction." In The Intellectual Roots of Independence: An Anthology of Puerto Rican Political Essays, eds. Iris M. Zavala and Rafael Rodríguez. New York: Monthly Review. 11-42. 